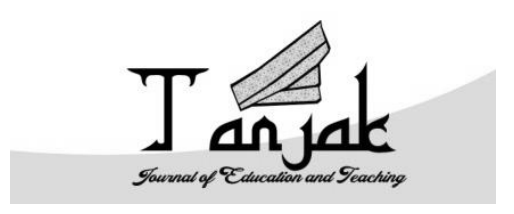

Tanjak: Journal of Education and Teaching

ISSN 2716-4098 (P) 2720-8966 (0)

Volume 1 Nomor 1, 2020

\title{
PARADIGMA STUDI ISLAM DI TENGAH PENDIDIKAN MODERN DAN GENERASI MILLENNIAL (INTERNET) KONTEKS MASYARAKAT EKONOMI ASEAN (MEA)
}

\author{
M. Alfan Sidik ${ }^{1}$ \\ muhammad_alfan@stainkepri.ac.id \\ 1STAIN Sultan Abdurrahman Kepulauan Riau, Tanjungpinang Kepulauan Riau 29132, \\ Indonesia.
}

DOI: https://doi.org/10.35961/tanjak. v1i1.70

\begin{abstract}
Abstrak
Salah satu yang terhegemoni era MEA adalah Pendidikan, sebagai sarana utama dalam rangka menyiapkan Sumber Daya Manusia SDM yang kompetitif. Namun muncul paradoks dengan adanya tantangan di MEA, Pendidikan hanya dimaknahi secara reduktif hanya untuk memenuhi tuntutan dunia industri. Sekolah tidak lagi dilihat sebagai upaya untuk mencapai nilai-nilai yang mulia. Era ini juga menandai lahirnya era baru, dengan bantuan perkembangan teknologi informasi modern (internet) dan segala manfaatnya, juga melahirkan paradoks, munculnya generasi millenial, generasi yang serba internet, dan justru semakin mengikis sense of bumanity, manusia yang didikte dan diarahkan oleh teknologi, manusia yang merasa paling tahu tentang segala hal, padahal hampir seluruh informasi didapat hanya melalui internet. Bahwa informasi itu valid atau hoax, itu urusan kesekian. Bagaimana paradigma studi Islam dengan berbagai kecenderungan yang ada, dalam menanggapi era ini. Tulisan ini ingin membahas paradigma studi Islam terutama di Perguruan Tinggi Agama Islam, dengan mempertimbangkan interkoneksitas tiga tradisi keilmuan Islam Ulum al-Diin, al-Fiker al-Islamiy dan Dirasat Islamiyyah, pemikiran M. Amin Abdullah. Yang nantinya menjadi
\end{abstract}

Tanjak: Jounal of Education and Teaching, Vol. 1, No. 1, 2020

http://ejournal.stainkepri.ac.id/index.php/tanjak 
sebuah formula dalam memaknahi dan menerapkan adagium "act locally and think globally" dalam pendidikan.

Kata kunci: MEA; pendidikan; paradigma studi islam; millennial; internet

\begin{abstract}
One of the hegemony of the MEA era is Education, as the main means in preparing competitive HR Human Resources. However, there is a paradox in the face of challenges in the MEA, Education is only reductively understood only to meet the demands of the industrial world. Schools are no longer seen as an effort to achieve noble values. This era also marked the birth of a new era, with the help of the development of modern information technology (the internet) and all its benefits, also gave birth to paradoxes, the emergence of millennial generation, the generation of the internet, and even more eroded the sense of humanity, humans dictated and directed by technology, people who feel they know the most about everything, even though almost all information is obtained only through the internet. That the information is valid or hoax, is the umpteenth affair. How is the paradigm of Islamic studies with various trends that exist, in response to this era. This paper would like to discuss the paradigm of Islamic studies, especially in Islamic Higher Education, by considering the interconnection of the three Islamic scientific traditions Ulum al-Diin, al-Fikr alIslamiy and Dirasat Islamiyyah, M. Amin Abdullah's thoughts. Which later will become a formula in slandering and applying adagium "act locally and think globally" in education.
\end{abstract}

Keyword: MEA; education; islamic study paradigm; mileniall; internet.

\title{
Pendahuluan
}

Masyarakat Ekonomi ASEAN (Asean Economic Community atau lebih dikenal MEA telah bergulir, suatu bentuk realisasi, dari intergrasi ekonomi di kawasan Asia Tenggara, yang salah satu fokusnya adalah pemerataan ekonomi di kawasan 10 Negara ASEAN, salah satu jalannya adalah dibukanya persaingan pasar bebas di kawasan regional ASEAN. Era MEA ini, pada akhirnya memang memberi pengaruh di segala sektor, tidak hanya sektor ekonomi. Setidaknya di sini, dua hal yang akan penulis soroti sebagai pijakan awal dari hegemoni MEA ini, Pertama; Pendidikan, yakni sebagai sarana utama dalam rangka menyiapkan Sumber Daya Manusia (selanjutnya disebut SDM) yang kompetitif. Seorang pakar pendidikan, pernah mengatakan bahwa "MEA sesungguhnya bukanlah persaingan produk atau barang melainkan persaingan SDM". Artinya SDM memang menjadi perhatian utama yang harus ditingkatkan melalui pendidikan.

Tanjak: Jounal of Education and Teaching, Vol. 1, No. 1, 2020

http://ejournal.stainkepri.ac.id/index.php/tanjak 
Kedua; Teknologi Informasi, MEA akan semakin mengafirmasi era globalisasi yang mengalami akselerasi berkali-kali lipat dengan bantuan perkembangan teknologi informasi modern (internet). Mudahnya akses informasi dan komunikasi melalui internet, didukung kecanggihan teknologinya, dan semakin tingginya penggunaan internet; media sosial (social-media) seperti facebook, twitter, dan sejenisnya, yang hampir tanpa batas, yang kian menuntut waktu, energi dan perhatian. Umumnya media baru ini dianggap membuka ruang untuk mengangkat suara, memperoleh informasi, berdebat, serta membentuk dan memperkuat relasi-relasi sosial baru. Oleh karena itu, di era ini, masyarakat bukan saja yang riil, namun juga telah muncul 'masyarakat' internet (netizen) dan 'masyarakat medsos' (social-media) yang juga tak kalah dalam memberi pengaruh perubahan-perubahan.

Kedua hal tersebut saling mempengaruhi, dan melahirkan berbagai gejala, Pertama, pendidikan akan sangat memfokuskan pada SDM yang kompetitif, dan akan memperoleh manfaat dari semakin mudahnya memperoleh informasi, pola hubungan guru-murid akan ikut terdemokratisasi, murid bisa memperoleh pengetahuan dari sumber-sumber lain di luar gurunya, peranan guru misalnya untuk memonopoli pengetahuan tidak lagi mutlak menentukan, murid bisa mengecek dan memvalidasi kebenaran apa yang dikatakan gurunya pada sumber-sumber lain (internet). Akhirnya peran guru hanya sebagai guide dalam mendapatkan pengetahuan, perangsang untuk belajar (motivator), dan patron dalam etika,(soal ketekunan, kedisiplinan, dan kejujuran).

Alternatif pendidikan dalam era ini juga semakin banyak dan bisa diperoleh dengan mudah. Orang tidak harus pergi keluar negeri untuk memperoleh pendidikan yang bermutu, justru lembaga luar negeri itulah yang datang dan membuka sekolah di sini. Universitas online dengan biaya yang lebih murah menjadi pilihan yang tak kalah menariknya. Maka tak akan ada lagi lembaga yang bisa mengklaim dirinya sebagai agen tunggal pendidikan dengan alasan apapun. Dengan banyaknya alternatif, orang semakin pintar untuk menentukan mana yang terbaik dan mempunyai peluang ivestasi masa depan untuk dirinya.

Dalam era persaingan bebas ini, perubahan tren juga terjadi dalam waktu yang relatif singkat, dan menuntut adanya kelincahan, dan kelenturan untuk siap menyesuaikan diri. Bukan hanya soal produk ekonomi, namun juga dalam pendidikan, orientasi pendidikan di level perguruan tinggi bukan lagi ke dalam,melainkan ke luar, yaitu ke pasar. Sejak beberapa tahun lalu, jurusan teknik masih menjadi yang paling diminati, dan jurusan ekonomi di berbagai perguruan tinggi tetap menjadi primadona. Sedang jurusan pendidikan yang dulu pernah menjadi favorit, cenderung stagnan bahkan menurun. Ke depan tren mungkin akan berubah. Oleh karena itu, kepekaan dalam membaca tren dan kesiapan untuk melakukan penyesuaian agar tetap mampu bersaing perlu dilakukan.

Tanjak: Jounal of Education and Teaching, Vol. 1, No. 1, 2020 
Gejala kedua, dalam era ini masyarakat akan hidup dalam era di mana horison sangat besar, yang memang sejak lama telah muncul pada era posmodern. Beberapa sebab akan membuat seseorang mengalami semacam tekanan psikologis, sehingga keyakinan menjadi goyah dan menjadi tidak berdaya, adanya terpaan informasi yang hampir tanpa filter, manusia tidak lagi merasa aman dengan sesuatu yang diyakininya. Hal inilah yang membuat ideologinya menjadi goyang, bahkan identitas lokalnya. Goncangan ini akan membuat manusia tidak bisa berpegang secara teguh sesuatu yang diyakininya. Kesadaran sebuah pegangan akan semakin kuat dirasakan oleh manusia kepada sesuatu yang stabil dan menawarkan kepastian.

Salah satu ekses dari gejala ini adalah orang akan menjadi primordial atau senang kumpul dengan yang sama-sama seperti dirinya, berbagai komunitas dan ormas-ormas pun bermunculan sebagai reaksi dari gempuran dalam tekanan era ini. Misalnya kemunculan kelompok-kelompok fundamentalisme dan radikalisme. Salah satunya contoh, sebagian orang sekarang mengalami kebingungan karena ada bermacam-macam Islam, kalau pada zaman dahulu atau di desa-desa mungkin orang hanya mengenal NU atau Muhammadiyah, dan sekarang ada Islam yang bermacammacam, yang masing-masing mengklaim memiliki dasar pembenarannya sendiri.

Tulisan ini ingin membahas tentang paradoks-paradoks yang muncul dari berbagai gejala yang terjadi dalam konteks MEA, era globalisasi ini sebagaimana yang dibahas di atas, serta bagaimana peran Studi Islam dan paradigma pengembangannya di Perguruan Tinggi Agama Islam untuk tidak terjebak dalam paradoks-paradoks di era ini.

\section{Pembahasan}

\section{Paradoks-paradoks Pendidikan Era Multikulturalisme}

Melihat berbagai gejala di Era MEA, memberikan pemahaman bahwa pada dasarnya dunia sekarang ini adalah dunia yang berjalan menurut kehendak pasar, karena itu, pendidikan tidak bisa lagi menutup mata terhadap apa yang diinginkan pasar, namun di sisi lain, hal inilah yang kemudian melahirkan paradoks-paradoks. Pendidikan pada akhirnya hanya dimaknahi secara reduktif hanya untuk memenuhi tuntutan dunia industri.

Raharjo (2014) menyatakan bahwa kebanyakan sekolah cenderung bersifat instrumentalis dalam menjawab tantangan era ini, yakni melihat pendidikan sekadar sebagai cara atau alat untuk mencapai target ekonomistik. Hal ini dapat terasa dalam kata kunci output yang ditawarkan pada peserta didik yang "berdaya saing”, (atau "kompetitif') untuk menggambarkan manusia yang hanya berubah menjadi "sumberdaya" (resource) untuk didayagunakan demi memantapkan persaingan regional dalam MEA. Meskipun hal tersebut dikemas dalam rangkaian kalimat muluk seperti,

Tanjak: Jounal of Education and Teaching, Vol. 1, No. 1, 2020 
"bermoral", "beretika", "berbudaya", yang semua tanpa landasan yang kongkrit. Tetapi hanya hidup dalam kebiasaan meniru ide-ide abstrak.

Reduksi ilmu di mana sekolah tidak lagi dilihat sebagai upaya untuk mencapai nilai-nilai yang mulia (sebagaimana Sokrates pernah berkata, "the unexamined life is not worth living" ("Kehidupan yang tak teruji, tak layak dijalani”)), tetapi lebih dimengerti sebagai jalan untuk memperoleh pekerjaan yang bergengsi. Di Perguruan Tinggi, Mata kuliah humaniora, seberapa pun dipandang perlu oleh ahli pendidikan, bagi mahasiswa akan dirasakan sebagai beban yang tidak penting. Mata kuliah tersebut dianggap tidak dapat memberikan sumbangan yang jelas bagi, misalnya, mereka yang ingin bekerja di Bank, di bidang komputer, di dunia Industri lainnya. Jika ilmu sudah dibatasi sedemikian rupa sehingga ia hanya menjadi sarana untuk memperoleh pekerjaan saja, kuliah dalam program sarjana tidak akan berbeda dengan kursus keterampilan saja. Perguruan tinggi tidak lagi dituntut untuk mencetak ilmuwan, tetapi tukang. Patokannya bukan tenaga yang siap berpikir dan berkreasi, melainkan tenaga yang siap pakai. Bukan knowledge dan awarness yang diharapkan dimiliki lulusan perguruan tinggi, melainkan skill (Bagir, 1997).

Maka paradigma pendidikan dalam konteks MEA yang multikultural ini, memiliki paradoks bahwa pendidikan memang harus berporos pada peningkatan SDM yang kompetitif, namun paradigma yang dibangun justru adalah melihat pendidikan secara instrumentalis, sebagai mesin pencetak sumberdaya yang bermanfaat untuk pola pembangunan yang bersandar pada rezim "pasar bebas", rezim yang sungguh tidak membebaskan. Bagi Freire, pemangkasan kebebasan inilah yang menjadi salah satu ciri pendidikan yang menindas.

Di tengah kecenderungan sistem persekolahan yang lebih banyak mengajarkan life skill unsich dengan pola pendidikan tiruan, di saat yang sama, muncul gejala lain, ditandai dengan tingginya penggunaan internet, utamanya di kalangan generasi millenial, generasi yang serba internet, dan justru semakin mengikis sense of humanity. Kepedulian antar manusia dirasakan sudah dirasakan menurun. Manusia era ini yang seharusnya dapat lebih memanfaatkan teknologi informasi, kenyantanya justru manusia yang didikte dan diarahkan oleh teknologi, manusia hari ini merasa paling tahu tentang segala hal, padahal hampir seluruh informasi didapat hanya melalui internet.

Salah satu efek lainnya dari era internet adalah generasi muda yang gadget addict, tak ada lagi anak-anak kecil bermain layang-layang, kelereng, petak umpet, dan permainan tradisional lainnya, mereka kecanduan berinteraksi di media sosial. Parahnya, statistik intensitas dalam mengakses konten-konten pornografi di internet juga makin meningkat. Generasi ini hidup dalam era yang serba instan, dengan sekejap mendapat informasi. Bahwa informasi itu valid atau hoax, itu urusan kesekian.

Apabila generasi millenial ini, -yang kadang secara pendidikan berasal dari sekolah-sekolah umum, yang notabene mengedepankan sains dan teknologi- merasa gelisah melihat perubahan

Tanjak: Jounal of Education and Teaching, Vol. 1, No. 1, 2020 
zaman, kemudian mereka justru tertarik kepada ajaran Agama, namun mereka belajar hanya mengandalkan dunia maya atau internet. Mereka mempelajari Islam dari situs yang tak jarang justru kepada situs yang menjelaskan Islam secara radikal. Menurut kementrian Agama sendiri, Tahun 2014, terdata lebih dari 9.800 situs yang dikelola oleh kelompok teroris.

Generasi seperti inilah yang menjadi sasaran empuk, masuknya ideologi-ideologi Islam ekstremis. adanya kesimpangsiuran lintas informasi mengenahi Islam dan klaim-klaim keislaman secara sepihak-subjektif, yang semakin hari semakin membingungkan masyarakat dan semakin tak terkontrol oleh siapapun dan oleh lembaga apapun, ditambah memuncaknya penggunaan media sosial, banyaknya hoax dan seterusnya —yang seringkali informasi tentang Islam yang tersebar tak terstruktur secara sistimatis baik segi materi maupun metodologi- menambah kesulitan masyarakat untuk memperoleh informasi yang memadai dan akurat tentang Islam.

Serbuan informasi dari hiruk-pikuk dunia maya-medsos, yang kini mulai dilihat sebagai pembuka dimensi baru bagi demokrasi dan hak asasi manusia, karena penggunanya memiliki kebebasan berekspresi dan berinteraksi. Sehingga suara-suara yang muncul dari media sosial ini juga dapat mengangkat imajinasi sosial/nasional ke ranah maya yang hampir tak terbatas, dan dapat memberi pengaruh dalam membentuk opini publik dalam masyarakat luas. Dalam media baru ini, pola-pola relasi sosial baru timbul dan tenggelam, proses mencari massa maya berlangsung dengan cepat dan pesat, dan tokoh-tokoh maya baru muncul dan hilang. Meskipun tak jarang suara-suara yang mucul sekadar menjadi pengulangan, perpanjangan "trend" hangat sesaat, atau sloganisme manipulatif.

Maka mengutip M. Amin Abdullah, bahwa diperlukan lagi memaknahi kembali istilah "act locally and think globally" yakni "bertindak dan berbuat di lingkungan masyarakat sendiri menurut aturan-aturan dan norma-norma tradisi lokal serta berpikir, berhubungan dan berkomunikasi dengan kelompok lain menurut cita rasa dan standar aturan etika global". Secara singkat 'Berpikir global dan bertindak lokal' sebuah adagium yang sudah muncul ke permukaan sejak dekade delapan puluhan, namun belum juga ditemukan formula yang dibutuhkan untuk dapat menerapkan prinsip adagium tersebut. Maka diperlukan sebuah formula untuk memaknahi adagium tersebut dalam konteks era MEA ini.

Kalau melihat gejala sosial sebagaimana yang dibahas sebelumnya, justru menunjukkan halhal yang sebaliknya. "act and think locally only", tanpa harus dibarengi "think globally". Dalam pergaulan, berhubungan dan berkomunikasi dengan kelompok lain tak merasa perlu mempertimbangkan dan mengindahkan tata aturan, hukum-hukum, kesepakatan-kesepakatan dan hubungan international. Masing-masing kelompok etnis, agama, kelas, kultur ingin mempertahankan, bahkan sekte, madzhab atau aliran pemikiran tertentu ingin mengokohkan dan mempertegas identitas lokal keagamaan, identitas kultural, identitas etnis, identitas politik karena

Tanjak: Jounal of Education and Teaching, Vol. 1, No. 1, 2020 
merasa di bawah bayang-bayang ancaman dominasi dan hegemoni kultur, budaya atau peradaban asing tertentu.

Maka pendidikan menurut M. Amin Abdullah masih merupakan alat yang dapat mencerahkan peradaban dengan kecenderungan semacam ini. Pendidikan keagamaan Islam yang terstruktur dan tersistimatisasi secara utuh, diharapkan dapat memberi peta yang utuh, lengkap dan komprehensif tentang keislaman amat diperlukan oleh warga masyarakat luas, termasuk para alumni perguruan tinggi umum, para penyelenggara negara dan para tokoh dan pemimpin gerakan sosial keagamaan.

Di tengah keputusasaan, despair, ketidakberdayaan dalam menghadapi realitas baru pasca revolusi industri dan hempasan gelombang revolusi Informasi dalam borderless society, diperlukan konsep-konsep baru yang dapat mencerahkan, yang dapat mengolah dan meramu kembali silabi, kurikulum, metode, pendekatan, filosofi pendidikan agama Islam yang dapat mengantarkan para peserta didik dan masyarakat luas untuk tetap dapat berpikir jernih, santun, etis, penuh pertimbangan yang rasional-logis dan dapat mengantarkan mereka untuk bertindak "act locally and think globally", tanpa harus mengorbankan salah satunya. Klaim keislaman secara subjektif-parsial yang semakin hari justru semakin membingungkan dan kebal akan kritik, yang justru akan memunculkan pola keislaman yang fundamentalisme inklusif dan pada akhirnya memicu radikalisme bahkan terorisme.

Salah satu formula yang ditawarkan oleh Abdullah (2007) dalam konteks mengaplikasikan paradigma "act locally and think globally" dalam Stusi Islam adalah dengan mempertautkan dan jaringan intelektual antara tradisi keilmuan Islam Ulum al-Diin, al-Fiker al-Islamiy dan Dirasat Islamiyyah..

\section{Paradigma Studi Islam Kontemporer di Perguruan Tinggi Islam}

Bagian ini akan membahas paradigma Studi Islam dalam konteks MEA, melalui tela'ah pemikiran M. Amin Abdullah, dalam mempertautkan antara Ulum al-Diin (Religious Knowledge), al-Fikr al-Islamiy (Islamic Thought) dan Dirasat Islamiyyah (Islamic Studies), dalam rangka melihat interkoneksitas ilmu pengetahuan, kluster keilmuan Islam dengan kelimuan-keilmuan modern seperti sosial dan humaniora, di tengah kecenderungan paradigma pendidikan yang instrumentalis dan mengesampingkan nilai-nilai keluhuran.

Menurut Abdullah (2009), pemahaman 'Ulum al-Dïn (ilmu-ilmu Agama) di sini akan dibatasi sebagai representasi "tradisi lokal" keislaman yang berbasis pada "bahasa" dan "teks-teks" atau nash-nash keagamaan, al-Fikr al-Islamiy (Pemikiran Islam) sebagai representasi pergumulan humanitas pemikiran keislaman yang berbasis pada "rasio-intelek", sedangkan Dirasat Islamiyyah (Studi Islam) atau Islamic Studies sebagai kluster keilmuan baru yang berbasis pada paradigma

Tanjak: Jounal of Education and Teaching, Vol. 1, No. 1, 2020 
keilmuan sosial kritis-komparatif lantaran melibatkan seluruh "pengalaman" (experiences) umat manusia di alam historis-empiris yang amat sangat beranekaragam.

Pemetaan dalam tradisi keilmuan Islam menjadi sangat penting dalam kerangka menemukan dialog yang positif-konstruktif antara yang "lokal" dan "global", antara yang "partikular" dan "universal", antara "distinctive values" dan "shared values", antara yang biasa disebut "dzanni" dan "qath'iy" dalam pemikiran fikih Islam dalam hubungannnya dengan keberadaan pandangan hidup dan pandangan keagamaan tradisi dan budaya lain (others; al-akhar) di luar budaya Islam. Terutama dalam menghadapi era multikulturalisme konteks MEA, diperlukan sebuah paradigma studi Islam di mana dapat dipertemukan antara tradisi keilmuan lokal dalam pola pengajaran ulum'udiin yang biasanya terdiri dari satu madzhab, dengan al-fikr al-Islamy yang sudah terdiri dari banyak wacana madzhab pemikiran, dan dengan Dirasat Islamiyah yang sudah menggunakan bantuan ilmu-ilmu lain, seperti sosial-humanitis.

Hubungan ketiga kluster keilmuan tersebut, akan dipotret dari perspektif sejarah perkembangan studi agama-agama yang telah melewati 4 (empat) fase, yaitu, lokal, kanonikal, kritikal dan global yang diambil dari Keith Ward, sebagaimana M. Amin Abdullah mengawalinya dari adopsi atas tahapan studi terhadap fenomena agama. Fase tersebut penulis rangkum dalam bentuk tabel berikut ini:

\begin{tabular}{|l|l|l|}
\hline No & Fase Keagamaan & \multicolumn{1}{|c|}{ Karakteristik } \\
\hline 1 & Fase Local & $\begin{array}{l}\text { Fenomena agama di era prasejarah (prehistorical period). Agama melibatkan } \\
\text { kultur, adat istiadat, norma, bahkan agama adalah fenomena lokal. Faktor } \\
\text { utama adalah bahasa dan batas-batas geografi. Fase ini juga dialami seluruh } \\
\text { agama di dunia, melahirkan habits of mind yang mengkristal menjadi belief. } \\
\text { Karakter lain dari fase local ketika bertemu dengan sistem adat, norma, dari } \\
\text { wilayah lain akan menimbulkan keraguan (doubt), dan menimbulkan } \\
\text { ancaman, yang kemudian diselesaikan dengan menolak, menghina, } \\
\text { menunduhkan, bertindak kejam, bahkan menyerang. Belum ada budaya } \\
\text { dan cara berfikir akan pentingnya partisipasi (participation) dan keikutsertaan } \\
\text { semua pihak yang berbeda untuk mengelola dan meredam konflik dengan } \\
\text { cerdas. }\end{array}$ \\
\hline 2 & Fase Canonical \\
atau Proporsional & $\begin{array}{l}\text { Fase ini ditandai dengan munculnya agama besar dunia (world religion) } \\
\text { seperti Agama-agama Ibrahimi (Abrahamic Religion) dan Agama-agama } \\
\text { Timur (Eastern Religion) yang kesemuannya memiliki panduan hidup moral, } \\
\text { hukum, dan sosial. Ditandai dengan adanya wahyu yang kebenarannya } \\
\text { dianggap final dan absolut yang termanifestasikan dalam Kitab Suci (Sacred }\end{array}$ \\
\hline
\end{tabular}

Tanjak: Jounal of Education and Teaching, Vol. 1, No. 1, 2020

http://ejournal.stainkepri.ac.id/index.php/tanjak 


\begin{tabular}{|c|c|c|}
\hline & & $\begin{array}{l}\text { Text), dan tradisi written (tulisan) atas aturan, norma, kesepakatan local. } \\
\text { Dalam tradisi-tradisi besar ini, agama tidak hanya berhubungan dengan } \\
\text { dunia spiritualitas, tetapi juga berusaha keras untuk mengatasi keinginan } \\
\text { manusia yang egoistik dan menjadikan pengetahuan tentang penyatuan } \\
\text { kembali dengan yang spiritual sebagai nilai tertinggi. Tetapi fase canonical ini } \\
\text { hampir seluruhnya memberikan pandangan dan pendapat tentang realitas } \\
\text { yang maha tinggi dalam berbagai penafsiran yang berbeda-beda. Dan juga } \\
\text { melibatkan sistem budaya (juga bahasa) dan politik masih pula bersifat } \\
\text { setempat (local), tidak jarang justru terbelenggu dalam konflik-konflik yang } \\
\text { tidak berekesudahan. }\end{array}$ \\
\hline 3 & Fase Critical & $\begin{array}{l}\text { Terinspirasi dari gerakan Enlightment di Eropa abad ke } 16 \text { dan 17. Dimana } \\
\text { agama-agama besar canonical menghadapi kritik tajam dan tantangan berat } \\
\text { untuk memikirkan kembali secara kritis habits of minds dan belief. Tantangan } \\
\text { tersebut adalah (1) prisnsip berfikir berdasar pada bukti konkrit di lapangan } \\
\text { (the principle of evidentalism) yang dipengaruhi oleh lahirnya disiplin-disiplin } \\
\text { ilmu; sehingga seluruh kepercayaan hendaknya secara proporsional } \\
\text { bersedia (legowo) untuk menghadapi pertanyaan dan pertanggungjawaban uji } \\
\text { public, dan (2) prinsip otonomi moral (the principle of moral autonomy) yang } \\
\text { bermakna bahwa persoalan hendaknya tidak dipecahkan atas otoritas. } \\
\text { Fase ini juga ditandai dengan munculnya 'doubt' yang diselesaikan dengan } \\
\text { melakukan pengamatan dan penelitian secara terus-menerus. Tradisi ini } \\
\text { selanjutnya membudaya dalam dunia akademisi dan penelitian yang } \\
\text { akhirnya memunculkan terminologi 'insider' dan 'outsider', 'objektive' dan } \\
\text { 'subjective', pembedaan antara faith dan tradition, juga essence dan manifestation } \\
\text { dari agama. }\end{array}$ \\
\hline 4 & Fase Global & $\begin{array}{l}\text { Ditandai dengan era borderless society dengan kemajuan teknologi informasi } \\
\text { sebagai bukti konkritnya. Munculnya imigrasi, diaspora, dan gerakan } \\
\text { transnationalisme. Dalam beberapa hal bencana juga menjadi sebab } \\
\text { pentingnya memikirkan kembali untuk menyusun atau menciptakan sistem } \\
\text { kehidupan keagamaan sebagai hasil adaptasi lingkup yang baru. }\end{array}$ \\
\hline
\end{tabular}

Berangkat dari pemetaan empat fase keagamaan di atas, tiga tradisi keilmuwan Islam, 'Ulum al-Diin, al-Fiker al-Islamiy dan Dirasat Islamiyyah, akan dilihat sebagai sebuah fase perkembangan tradisi keilmuan Islam.

Tanjak: Jounal of Education and Teaching, Vol. 1, No. 1, 2020 


\section{a. Ulum al-Diin, al-Fikr al-Islamiy dan Dirasat Islamiyyah Sebagai Sebuah Fase}

'Ulumuddin' istilah yang sebenarnya telah digunakan oleh Imam Abu Hamid al-Ghazali, pada abad 10 dan 11. Di sini istilah Ulum al-Dïn (Religious knowledge), merujuk kepada ilmu-ilmu agama (Islam) seperti aqidah dan syariah dengan menggunakan ilmu bantu bahasa (yang dapat membantu memahami kandungan dan arti nash atau teks kitab suci) dan logika deduktif yang merujuk dan menderivasi hukum-hukum, aturan-aturan dan norma-norma agama dari kitab suci. Dari sana lalu muncul kluster ilmu-ilmu agama (Islam) seperti Kalam, Fikih, Tafsir, Hadis, Qur'an, Faraidl, Aqidah, Akblaq, Ibadah dan begitu seterusnya dengan ilmu bantunya bahasa Arab (Nahwu, Saraf, Balaghah, Badi', 'Arudl).

Fase Ulum al-Diin (Ilmu-ilmu Agama Islam) kemudian mengalami perkembang menjadi fase al-Fikr al-Islamiy (Pemikiran Islam )ketika subjek kajiannya menjadi lebih luas yaitu bahan dasar atau bahan pokok (Ushuluddin) keagamaan Islam ini terkumpul dan kemudian disusun secara sistematis dan terstruktur secara akademis dengan melibatkan pendekatan sejarah pemikiran (Origin, Change dan Development), maka munculah fase al-Fikr al-Islamiy (Pemikiran Islam).

Pada fase pertama Ulum al-Diin, karakteristik studi Islam lebih ditekankan pada kajian tertentu dari madzhab dalam agama (lokal), dan sifat pembelajaran dan pengajaran fase ini adalah parsial (sepotong-potong) dan provincial (terkotak-kotak-terbatas cara pandangnya), dan parocbial (sempit). Dalam arti, tanpa disadari oleh para pelaku dan aktor yang berada di belakangnya, mereka cenderung masih terjatuh pada pemihakan al-Firaq al-Islamiyyah tertentu dan belum sampai masuk ke al-Firaq al-Islamiyyah. Maka pengajaran 'Ulum al-Dïn terkesan menjadi dangkal, rentan terhadap konflik-konflik-untuk tidak menyebutnya sangat rentan terhadap tindak kekerasan antar kelompok-tidak mendalam dan tidak komprehensif. Studi 'Ulum al-Diin di berbagai tempat di dunia, termasuk Indonesia, hampir-hampir kehilangan horizon keilmuan keislaman yang utuh, luas dan komprehensif. Pengajaran 'Ulum al-Diin kontemporer lebih bercorak partial, reduktif, selektif, tanpa melihat ketersambungan dan keterkaitannya dengan kluster yang lain dalam satu rumpun disiplin keislaman. Dengan begitu tidak cukup lagi orang yang belajar Islam hanya terbatas pada Ulum al-Diin yang parsial, parochial, sectarian, provincial, dan reduktif, jika seseorang ingin mempelajari khazanah intelektual Islam secara utuh, mendalam dan komprehensif.

Karakteristik para ilmuwan Ulum al-Diin ini dalam beberapa aspek menjadi out of date dan tidak dapat digunakan untuk memahami perkembangan dan kesejahteraan ilmu itu sendiri. Maka, fase kedua yaitu al-Fikr Islamiy berangkat dari kebutuhan tersebut, yakni ingin mempelajari khazanah intelektual Islam secara utuh, mendalam dan komprehansif. Maka fase ini menggunakan pendekatan yang lebih historis, sistematis, utuh-komprehensif, non sektarian, tidak provincial, tidak

Tanjak: Jounal of Education and Teaching, Vol. 1, No. 1, 2020 
parocbial, yang sebenarnya sangat menolong untuk mengisi kekurangan yang ada pada corak pembelajaran dan praktik pengajaran Ulum al-Diin di atas.

Maka ketika pergumulan dan silang pendapat antara Ulum al-Dïn dan al-Fiker al-Islamiy belum selesai dan belum duduk, dunia akademis keilmuan Islam terus berkembang, mengikuti perkembangan ilmu-ilmu dan metode-metode penelitian yang umum ada di dunia akademis pada umumnya. Publikasi hasil penelitian lapangan, hadirnya e-journal keilmuan keislaman, simposium, seminar-seminar keilmuan, encyclopedia, terbitnya buku-buku baru dari manapun datangnya, baik dari insiders maupun outsiders, mulai merangsek masuk ke pusat-pusat studi keislaman baik di Barat maupun Timur. Dengan munculnya berbagai metode dan pendekatan baru yang muncul mulai abad ke 18-19, baik yang disebut filologis-historis dan lebih-lebih social sciences, maka munculah fase ketiga, cluster baru keilmuan Islam yang disebut dengan Dirasat Islamiyyah atau Islamic Studies.

Dalam kluster keilmuan ini, cara kerja untuk memperoleh data (process dan procedure), cara berpikir mendekati persoalan akademik yang dihadapi (approaches), asumsi-asumsi dasar yang digunakan (basic assumption) sangatlah berbeda dari kedua jenis keilmuan keislaman sebelumnya. Kluster ini menggunakan pendekatan kritis dan comparative (perbandingan), historis, psikologis, antropologis atau sosiologis terhadap realiotas keberagaman muslim, yang ditopang dan diperkokoh oleh research (penelitian) lapangan. Dengan kata lain, Dirasat Islamiyyah selalu menggunakan dan menggandeng metode kerja tata pikir ilmu-ilmu sosial untuk membedah realitas keberagamaan Islam di alam nyata kehidupan sehari-hari, tidak hanya di alam teks dan tidak pula hanya terbatas pada alam rasio (Bagir, 2005).

Isu-isu yang dibahas dan diperbincangkan dalam Dirasat Islamiyyah pun adalah isu-isu kontemporer seperti Hak Asasi Manusia, gender, pluralitas agama, hubungan dan hukum Internasional yang menggunakan metode dan pendekatan campuran antara al-Fikr al-Islamy dan Dirasat Islamiyyah. Untuk memperjelas perbedaan ketiga kluster keilmuwan tersebut, Penulis rangkum dalam bentuk tabel berikut ini;

\begin{tabular}{|l|l|l|l|}
\hline $\begin{array}{l}\text { Tiga fase } \\
\text { keilmuwan } \\
\text { Islam }\end{array}$ & Metode dan Pendekatan & Produk-produk Keilmuwan & Isu-Isu pembahasan \\
\hline Ulum al-diin & $\begin{array}{l}\text { Menggunakan ilmu bantu } \\
\text { bahasa dan logika } \\
\text { deduktif. Partial-tidak } \\
\text { utuh, reduktif, selektif, } \\
\text { parochial, sectarian, } \\
\text { provincial. }\end{array}$ & $\begin{array}{l}\text { Ilmu-ilmu agama seperti } \\
\text { aqidah dan syari'ah. (kalam, } \\
\text { fikih, Hadis, al-Qur'an, } \\
\text { Faraid) }\end{array}$ & $\begin{array}{l}\text { Tauhid, Keadilan, } \\
\text { janji dan ancaman, as- } \\
\text { sam' (periwayatan) dan } \\
\text { Rasio. }\end{array}$ \\
\hline
\end{tabular}

Tanjak: Jounal of Education and Teaching, Vol. 1, No. 1, 2020

http://ejournal.stainkepri.ac.id/index.php/tanjak 


\begin{tabular}{|c|c|c|c|}
\hline $\begin{array}{l}\text { Al-fiker Al- } \\
\text { Islami }\end{array}$ & $\begin{array}{l}\text { Historis, Komprehensif } \\
\text { dan Sistematis. } \\
\text { Komprehensif-utuh, non } \\
\text { sectarian, tidak parochial } \\
\text { dan tidak provincial. }\end{array}$ & $\begin{array}{l}\text { Studi Al-Qur'an dan Sunnah, } \\
\text { pemikiran hukum, pemikiran } \\
\text { Kalamiyyah, pemikiran } \\
\text { Mistik, ekspresi artistik, } \\
\text { pemikiran Filsafat, pemikiran } \\
\text { politik. }\end{array}$ & $\begin{array}{l}\text { Ushul Figh, } \\
\text { Perbandingan } \\
\text { Madzhab. }\end{array}$ \\
\hline $\begin{array}{l}\text { Dirasat } \\
\text { Islamiyyah }\end{array}$ & $\begin{array}{l}\text { Kritis dan comparative } \\
\text { (perbandingan), historis, } \\
\text { psikologis, antropologis } \\
\text { atau sosiologis. yang } \\
\text { ditopang dengan (principe } \\
\text { of evidentalisme), reseach } \\
\text { (penelitian) lapangan, } \\
\text { pengamatan historis- } \\
\text { empiris yang objektif, } \\
\text { ketersambungan } \\
\text { (continuity) dan perubahan } \\
\text { (change), pola (pattern). }\end{array}$ & $\begin{array}{l}\text { HAM dan Islam, Demokrasi } \\
\text { dan Islam, Pluralisme Agama. }\end{array}$ & $\begin{array}{l}\text { HAM,gender, } \\
\text { pluralitas agama, } \\
\text { hubungan dan hukum } \\
\text { Internasional. }\end{array}$ \\
\hline
\end{tabular}

Jika dilihat dari perspektif ke empat tahapan atau fase studi agama (local, canonical, critical dan global) di atas, maka tampak bahwa 'Ulum al-Diin masih pada tahapan Canonical-bahkan dengan uraian di atas terbaca bahwa sebagiannya telah merosot ke fase "local", dalam arti, parochialprovincial-sedangkan al-Fikr al-Islamiy berada pada masa transisi ke arah pematangan munculnya Dirasat Islamiyyah yang bercorak Critical. bisa dilihat skema berikut ini;

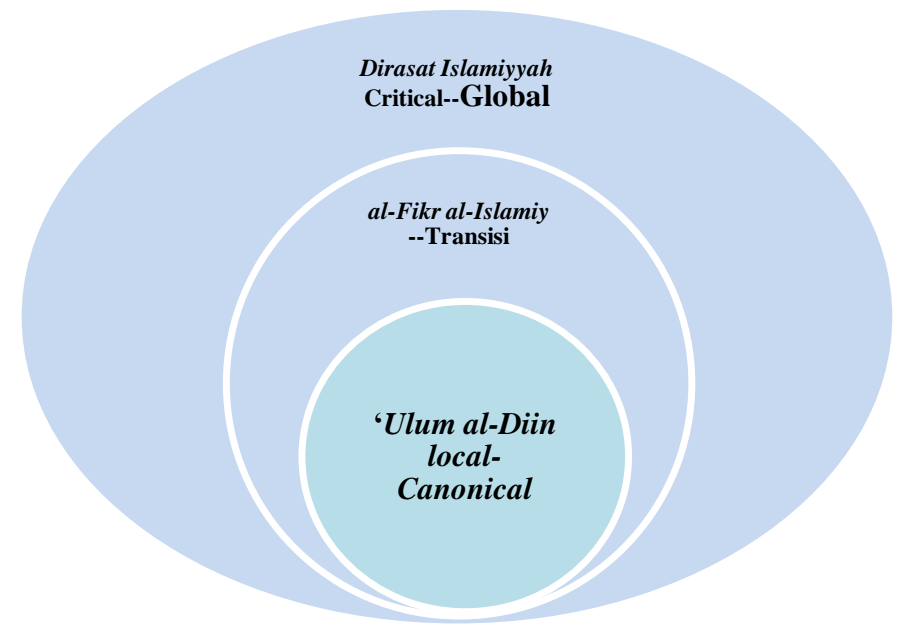

Tanjak: Jounal of Education and Teaching, Vol. 1, No. 1, 2020

http://ejournal.stainkepri.ac.id/index.php/tanjak 
Memang hubungan, persentuhan, dan perkembangan dari satu fase tertentu ke fase yang lain tidak dapat berjalan mulus, bahkan terputus-putus. Hal ini dikarenakan adanya goncangangocangan yakni sikap ekslusifisme dan tidak rela (tidak legowo) pada pemegang tradisi pemikiran localcanonical, jika tradisi alam pikiran critical -apalagi Global_ikut campur memasuki domain mereka yang telah dijaga dan dipelihara berabad-abad.

Maka yang terjadi adalah munculnya jargon-jargon, dalam pemikiran dan ideologi konfliktual Kalamiyyah era Local-Canonical yang muncul kembali dan sangat populer saat sekarang ini di tanah air melalui gerakan-gerakan sosial keagamaan Islam. mereka mulai berafiliasi dengan politik. Mencampuradukkan tuduhan pemurtadan, pendangkalan aqidah, dan pensyahadatan ulang, dengan tuduhan liberal, sekuler, pluralisme dalam satu paket. Inilah cermin dari kesulitan positioning dalam mendialogkan dan mempertautkan antara kluster 'Ulum al-Dïn, kluster al-Fiker al-Islamiy dan kluster Dirasat Islamiyyah. Sejatinya, para pecinta dan penggemar ketiga kluster keilmuan ini tidak perlu membangun "tembok tebal" pemisah antara ketiga kluster keilmuan keagamaan (Islam) tersebut.

Rauf (2010) menyatakan bahwa para pecinta 'ulum al-Diin yang masih bersifat lokal dan cenderung ekseklusif, akan menjadi sasaran empuk, masuknya ideologi-ideologi Islam ekstremis. Pemahaman satu sumber yang salah tentang jihad misalnya dapat membawa seseorang masuk ke dalam ideologi radikalisme. Maka dari itu, sekian banyak mereka yang "terbujuk" dengan ideologi ekstremis ini, yang menarik adalah kebanyakan lulusan-lulusan dari bidang sains umum, yang kebanyakan mereka memahami Islam tanpa memiliki dasar yang utuh dan kurang wacana pemikiran dari kluster keilmuan al-fiker al-Islami dan Dirasat Islamiyah, mengakibatkan pemahaman Islam secara Hight Islam bukan Low Islam.

Meski sepertinya tidak saling bersambung, sebenarnya ketiganya masih saling berkaitan, saling meminjam, dan bahkan dalam kerangka tertentu justru bisa saling menguatkan. Karenanya, mesti dipahami betul bahwa relasi di antara ketiga kluster ini bukanlah bersifat hierarkis saling meninggalkan di antara ketiganya.

\section{Ilmu-Ilmu Sosial dan Humanitas sebagai Ilmu Bantu Studi Islam di Era Kontemporer konteks MEA}

Untuk mengahadapi tantangan-tantangan yang muncul sebagai akibat langsung dari gejalagejala di Era Globalisasi dalam konteks MEA, yang semakin menperluas wilayah pengalaman dan penghayatan kemanusiaan. Munculnya isu-isu kemodernan, seperti gender, HAM, hak non-Muslim, ide tentang kemajuan dan seterusnya, maka dalam pengembangan Dirasat Islamiyyah (studi Islam) diperlukan bantuan dari ilmu-ilmu lain misalnya ilmu sosial dan budaya untuk mengembangkannya.

Tanjak: Jounal of Education and Teaching, Vol. 1, No. 1, 2020 
Oleh karena itu, munculnya generasi baru Dirasat Islamiyyah (studi Islam) sangat menekankan pendekatan kritis dan komparatif dan menggunakan metode kerja ilmu-ilmu sosial untuk membedah realitas keberagamaan Islam tidak hanya pada teks, ataupun wilayah kognitif, tetapi juga fakta empiris. Munculnya tradisi Post-Orientalisme disebut-sebut sebagai pembuka dari Dirasat Islamiyyah di mana pendekatan dan studi terhadap Islam perlu melibatkan pertemuan antara teks-teks dasar (foundational texts) dengan persoalan dan perdebatan yang muncul baik di lingkup masyarakat muslim (pelaku) dan juga temuan-temuan para ilmuwan.

Maka bantuan ilmu-ilmu sosial dan humanitas kontemporer sangat diperlukan. Salah satu usulannya adalah lewat pengenalan bagian-bagian tertentu dari ilmu-ilmu sosial kritis dan humanaties kontemporer yang dikawinkan dengan budaya lokal yang mendarah mendaging dalam payung Ulum al-Diin dalam konteks budaya Islam. Dengan bantuan cara berpikir dan metode ilmuilmu sosial, yang salah satunya menggunakan prinsip evidentalisme (selalu melibatkan dan mempertimbangkan data-data dan fakta-fakta konkrit di lapangan), manusia dan umat beragama pada umumnya menyadari benar adanya fakta sosial (belum lagi politik dan ekonomi) yang ada di hadapan dan mengelilingi mereka adalah sangat keras.

Maka studi Islam sangatlah berbeda dengan studi-studi lainnya seperti ekonomi, politik, sosial dan sebagainya bahkan kimia, fisika dan biologi, studi Islam memiliki keunikan dan kekhasan tersendiri, khususnya fenomenologi agama yang salah satu karakteristiknya adalah menentang reduksionisme, oleh karena itu ia menggunakan seperangkat metodologi ilmu-ilmu sosial yang bersifat interdisiplin. Keunikannya atau mungkin kesulitanya pertama, adalah dalam studi agama keterlibatan "subjek" sangatlah kental namun di sisi lain ada "objek" di luar subjektivitas dari pengkaji yang tidak dapat dinafikan. Meskipun “objek-objek" di luar "subjek" tadi (pengkaji/peneliti) juga memiliki "subjektivitasnya" sendiri-sendiri. Dengan demikian sejak awal berangkat studi agama memang bersifat objektif-cum-subjektif atau subjektif-cum-objektif.

Kedua, yang menjadi ciri khas studi Islam adalah adanya unsur Nonfalsifiable Postulated Alternate Realities, yaitu adanya kepercayaan, keimanan, akidah, credo, yang diasumsikan pasti benar adanya, dan tidak dapat dipertanyakan dan dipermasalahkan oleh siapa pun. Tidak mengenal falsifikasi dan verifikasi seperti umumnya dikenal dalam ilmu-ilmu dan wilayah bidang studi yang lain. Namun pada kenyataannya, di alam praktik historisitasnya ada sebagaian atau seluruh yang semestinya masuk wilayah falsifiable justru dimasukkan dalam wilayah Nonfalsifiable. Karena adanya interpretasi-interpretasi para tokoh-tokoh besar, para pelaku sejarah pendiri madzhab, aliran-aliran, pemangku kepentingan, relasi kuasa, kelengkapan sumber yang digunakan, situasi sosial-budaya dan politik yang mengelilinginya dan begitu seterusnya.

Maka agar tidak sampai terjadi distorsi atau reduksi yang berlebihan terhadap fenomena keberagamaan manusia, maka pendekatan model applied sciences baik dalam bentuk sosiologi, sejarah

Tanjak: Jounal of Education and Teaching, Vol. 1, No. 1, 2020 
maupun psikologi terhadap agama dirasa perlu untuk dilengkapi dengan jenis pendekatan dan pemahaman lain yang bersifat fenomenologis, yaitu suatu bentuk pendekatan keilmuan yang berusaha mencari hakikat atau esensi dari apa yang ada dibalik segala macam bentuk manifestasi agama dalam kehidupan penganutnya.

Maka dengan masukan fenomenologi agama yang memanfaatkan ilmu-ilmu sosial kritis, dapat membantu Islamic Studies atau Dirasat Islamiyyah keluar dari paradigma Ulum al-Diin, yang belum memanfaatkan masukan-masukan dan temuan-temuan ilmu-ilmu sosial. Ilmu-ilmu sosial berangkat dari kancah lapangan yang konkrit, objektif, ada dengan sendirinya, tanpa intervensi dan rekayasa dunia subjektif. Fakta-fakta di lapangan-lah yang menjelaskan fenomena dengan sendirinya.

Fenomenologi agama—seperti halnya fenomenologi pada umumnya-menuntut penyisihan sikap menilai (judgment) oleh peneliti terhadap objek yang ditelitinya. Pada saat yang sama ia merupakan pemberontakan terhadap meruyaknya metode-metode penelitian yang dihasilkan dari sanis-sains teoritis, khususnya sosiologi dan sejarah (baca; historisisme). Hakikat fenomenologi memang tak lain dari pada penyangkalan terhadap asumsi sifat-sifat manusia, sifat emosi, sifat-sifat masyarakat, sifat-sifat dunia, dan sebangsanya yang cenderung menyarati teori-teori semacam ini. Sifat "siap pakai" teori-teori semacam ini memendam potensi penggagahan dan manipulasi fakta. Sebagai gantinya, fenomenologi menuntut partisipasi-empati, kalau bukan malah simpati-sang peneliti terhadap objek penelitiannya. Seperti diungkapakan oleh salah seorang orientalis terkemuka, Wilfred Cantwell Smith, sebuah observasi tentang Islam baru bisa dinyatakan benar bila kaum muslim sendiri membenarkannya.

\section{Kesimpulan}

Sebagai kesimpulan beberapa poin dapat penulis sampaikan, bahwa gejala-gejala yang muncul di Era MEA semakin mengafirmasi era Globalisasi, ditandai dengan tingginya penggunaan internet, utamanya di kalangan generasi millenial, akan memberikan kemudahan-kemudahan, dalam pendidikan akan memudahkan dalam memperoleh informasi dan berbagai kemudahan lainnya. Sisi lain dari era ini, justru semakin mengikis sense of bumanity. Kepedulian antar manusia dirasakan sudah menurun. Manusia era ini seharusnya dapat lebih memanfaatkan teknologi informasi, nyantanya justru manusia didikte dan diarahkan oleh teknologi, manusia hari ini merasa paling tahu tentang segala hal, padahal hampir seluruh informasi yang didapat hanya melalui internet. generasi pada era ini, adalah generasi muda yang gadget addict, mereka kecanduan berinteraksi di media sosial. Generasi ini hidup dalam era yang serba instan, dengan sekejap mendapat informasi. Bahwa informasi itu valid atau hoax, itu urusan kesekian.

Tanjak: Jounal of Education and Teaching, Vol. 1, No. 1, 2020 
Pendidikan pada akhirnya mempunyai peran yang sangat penting, dalam menghadapi era Multikultural konteks MEA ini, Paradigma pendidikan satu sisi tidak harus terjebak dalam memandangnya hanya sebagai instrumen ekonomi tanpa mempertimbangkan sisi-sisi lainnya seperti pemahaman agama secara utuh. Terutama paradigma pendidikan Islam, sudah seharusnya mengembangkan paradigma keilmuan Islam yang sesuai dengan era multikulturalisme konteks MEA.

Salah satu pengembangan Paradigma studi Islam khususnya di Perguruan Tinggi Agama Islam, dengan mempertautkan ketiga kluster keilmuan Islam Ulum al-Dïn, al-Fiker al-Islamiy dan Dirasat Islamiyyah. Pertama dengan kembali memahami perbedaan watak dasar dan struktur fundamental cara kerja dari ketiga kluster keilmuan tersebut.

Kedua dengan mempertautkan ketiga kluster keilmuan tersebut, cara mempertautkannya bukan dengan pola hubungan yang bercorak single entity (entitas tunggal; hanya mengenal satu kluster sedang kluster-kluster yang lain tidak dikenal), bukan pula dengan separated entities (ketiga kluster ada, tetapi terpisah-pisah dan tak saling terhubung, tidak saling berkomunikasi antara yang satu dan lainnya). Akan tetapi dengan pola integrated entities yakni ketiga kluster tersebut saling terpaut dan terhubung, berikut implikasi dan konsekwensinya masing-masing pada dataran praktis di lapangan. maka upaya serius untuk mempertautkan ketiga kluster pilar studi Islam tersebut layak dipertimbangkan dengan sungguh-sungguh, sebagai langkah awal dalam memaknahi dan menerapkan adagium lama "berpikir global, bertindak lokal".

\section{Ucapan Terima Kasih}

Terima kasih penulis ucapkan kepada pihak-pihak yang telah membantu dan memberikan dukungan hingga tulisan ini selesai tepat pada waktunya.

Tanjak: Jounal of Education and Teaching, Vol. 1, No. 1, 2020 


\section{Referensi}

Abdullah, M. Amin. (2007). Studi Islam, Ilmu Humaniora dan Sosial: Sebuab Perspektif Terpadu. Yogyakarta: Elsaq-Press.

Abdullah, M. Amin. (2009). Mempertautkan Ulum Al-Diin, Al-Fikr Al-Islamiy dan Dirasat Islamiyyab: Sumbangan Keilmuan Islam untuk Peradaban Global, dalam Mereka Bicara Pendidikan Islam; Sebuah Bunga Rampai. Jakarta: DPP GUPPI.

Bagir, Haidar. (1997). Rahasia Wajah Suci (Memahami Islam secara fenomenologi). Bandung: Mizan.

Bagir, Zainal Abidin, dkk. (2005). Integrasi Ilmu dan Agama Interpretasi dan Aksi. Bandung: Mizan.

Ernest, Gellner. (1992). Postmodernism Reason and Religion. Canada: Routlege.

Raharjo, Toto. (2014). Sekolah Biasa Saja. Yogyakarta: Progres..

Rauf, Muhammad Abdul . (2010). Interpretasi Orang Luar Tentang Islam: Sudut Pandang Muslim. Yogyakarta: Suka-Press.

Tanjak: Jounal of Education and Teaching, Vol. 1, No. 1, 2020

http://ejournal.stainkepri.ac.id/index.php/tanjak 